九州大学学術情報リポジトリ

Kyushu University Institutional Repository

\title{
Translateral Orbital Wall Approach to the Orbit and Cavernous Sinus : Anatomic Study
}

松尾，諭

ht tp://hdl. hand le. net/2324/1785364

出版情報：九州大学，2016，博士（医学），課程博士 バージョン：

権利関係：やむを得ない事由により本文ファイル非公開（2） 
氏名：松尾 諭

論 文名：Translateral Orbital Wall Approach to the Orbit and Cavernous Sinus:

Anatomic Study

(経眼窩外側壁アプローチによる眼窩と海綿静脈洞への到達: 解剖学的検討)

区 分：甲

\section{論文内容の要旨}

眼窩内病変や海綿静脈洞病変に対する手術アプローチはこれまでよく検討されてきた が、眼窩と海綿静脈洞の両方を巻き込む病変に対するアプローチは、今日においても困 難である。本研究では 7 側のホルマリン固定後の成人屍体標本(眼窩および海綿静脈洞) を手術顕微鏡と内視鏡を用いて解剖し、眼窩と海綿静脈洞の顕微鏡的および内視鏡的微 小解剖と orbitozygomatic アプローチと translateral orbital wall アプローチの手術解剖を 提示した。orbitozygomatic アプローチでは眼窩上および外側面、視神経管、上眼窩裂、 海綿静脈洞を露出でき、この領域の手術操作に十分な術野を確保できた。 translateral orbital wall アプローチでは眼窩外側壁、視神経管と上眼窩裂さらに、海綿静脈洞の外側 壁まで露出することが可能であった。しかしながら眼窩尖部やその周囲の海綿静脈洞へ の術野は狭く深いものであった。内視鏡補助下では術野を広く観察することができ、と りわけ前床突起周囲や下顎神経後方の露出が可能になると思われた。内視鏡補助下 translateral orbital wall アプローチは眼窩および海綿静脈洞に到達可能であり、全切除不 可能あるいは眼窩および海綿静脈洞の外側に限局した比較的小さな病変に対しては orbitozygomatic アプローチの代替になりうると考えられた。 